\title{
Pathogenic serum IgG anticardiolipin antibodies and the idiotypic network
}

\author{
Jacob Cohen, Ronit Bakimer, Miri Blank, Guido Valesini, Yehuda Shoenfeld
}

\begin{abstract}
Objectives-To determine whether active immunisation of mice with pathogenic anticardiolipin antibodies (IgG and IgM), derived from the serum of a patient with the antiphospholipid syndrome, could dysregulate the idiotypic cascade and induce the production of anti-anti-anticardiolipin (Ab3) with anticardiolipin activity by the mice with the association of overt antiphospholipid syndrome.

Methods-Anticardiolipin antibodies were purified from the serum of a patient with the antiphospholipid syndrome. The purified anticardiolipin antibodies were used to immunise mice at the footpads and the mice were then followed up for serological and clinical manifestations of the antiphospholipid syndrome.
\end{abstract}

Results-The IgG anticardiolipin antibody was found to be monospecific and to bind cardiolipin with high affinity. Immunisation of naive BALB/c mice with the purified IgG anticardiolipin antibody was followed by production in the mice of sustained high titres of IgG anticardiolipin antibody, associated with a prolonged activated partial thromboplastin time $(64.5(9.7) v 30.1(1 \cdot 7)$ seconds in control mice) and thrombocytopenia $(0.4$ $(0.06) \times 10^{9} v 1.0(0.09) \times 10^{9} / 1$ platelets in controls). The titres of other autoantibodies (for example, antibodies to DNA, histone), though high after the immunisation, decreased rapidly and were almost undetected one month after the boost injection. The mice immunised with the IgG anticardiolipin antibody showed low fecundity $(36 \%$ of mice became pregnant $v 62 \%$ in the group immunised with control IgG). The pregnant mice had an increased resorption rate (the equivalent of fetal loss in the human) of $61(9) \% v 5(4) \%$ in the control group. The mean (SD) embryo and placental weights in mice with the antiphospholipid syndrome were significantly lower than in the mice injected with control IgG (641 (210) and 103 (14) $\mathrm{mg} v$ 1303 (105) and 145 (8) $\mathrm{mg}$ respectively.

The IgM anticardiolipin antibodies purified from the same patient were found to be polyspecific, binding with low affinity to anticardiolipin antibodies and double stranded DNA, and carried the anti-DNA idiotype 16/6. Mice immunised with the purified IgM anticardiolipin antibodies, though showing reduced fecundity (30\%), had only a slightly increased resorption rate $(12$ (9) $v 3(5) \%$ in controls) and only a slight and statistically non-significant decrease in mean (SD) embryo and placental weights (1134 (188) and 136 (11) $\mathrm{mg}$ respectively). Conclusions-The results confirm the induction of pathogenic anticardiolipin antibodies by immunisation with serum anticardiolipin, dysregulating the idiotypic network, and point to the higher pathogenic potential of serum IgG $v$ IgM anticardiolipin antibodies.

(Ann Rheum Dis 1993; 52: 742-748)

The antiphospholipid syndrome is characterised by the presence of anticardiolipin antibodies or lupus anticoagulant, or both, associated with recurrent venous and arterial thromboembolic phenomena, thrombocytopenia, and recurrent fetal loss. ${ }^{1-4}$ A great variety of additional manifestations have been attributed to the syndrome..$^{5-7}$ Many theories have been reported to explain the hypercoagulable state on the background of thrombocytopenia ${ }^{8-11}$ and the conclusive therapeutic recommendations are still awaiting double blind studies. ${ }^{12-14}$

In part, the unresolved enigmas about the antiphospholipid syndrome are due to the lack of proper experimental models in animals. Several such models have now been reported some use mice genetically prone to systemic lupus erythematosus (SLE) (MRL/lpr), ${ }^{15}$ whereas others use an induced syndrome. ${ }^{16}{ }^{17}$

We have shown the induction of the antiphospholipid syndrome in naive mice in two independent ways: (a) passive transfer of human and mouse polyclonal and monoclonal anticardiolipin antibodies was followed by thrombocytopenia and a high resorption rate of fetuses in pregnant mice ${ }^{17}$; and $(b)$ active immunisation, previously shown to induce SLE. ${ }^{18-20}$ In the second method we injected $1 \mu \mathrm{g}$ human monoclonal anticardiolipin antibodies $(\mathrm{H}-3)^{21}$ into the hind footpads of $\mathrm{BALB} / \mathrm{c}$ mice, which resulted in sustained high levels of anticardiolipin antibody titres in the mice (anti-anti-anticardiolipin (Ab3)) which, when pregnant, also showed a high rate of fetal loss. ${ }^{22}$

We report here the active induction of the antiphospholipid syndrome in BALB/c mice using immunisation with a polyclonal serum anticardiolipin antibody derived from the same patient whose anticardiolipin antibodies were 
reported to induce the syndrome on passive transfer. ${ }^{17}$ Interestingly, only the IgG anticardiolipin antibodies of the patient's serum induced significant thrombocytopenia, increased resorption rate and prolonged activated partial thromboplastin time, whereas low fecundity rate was observed in mice immunised with IgG and IgM antibodies.

\section{Materials and methods}

PATIENT

The patient was a 23 year old woman with a primary antiphospholipid syndrome. From the age of 16 she had had a positive Venereal Disease Research Laboratories (VDRL) test, prolonged activated partial thromboplastin time ( $>55$ seconds), and three episodes of deep vein thrombosis in her legs. High titres of anticardiolipin antibodies of the IgG and IgM isotypes were detected in her serum.

Serum from a healthy subject negative for anticardiolipin antibodies was used as a control.

PRECIPITATION OF SERUM IMMUNOGLOBULINS WITH $\left(\mathrm{NH}_{4}\right)_{2} \mathrm{SO}_{4}$

A saturated solution of $\left(\mathrm{NH}_{4}\right)_{2} \mathrm{SO}_{4}$ was prepared by adding $1000 \mathrm{~g}$ crystals to 1 litre distilled water. After stirring and filtering the $\mathrm{pH}$ was adjusted to $7 \cdot 4$. For precipitation we used $50 \%$ saturation adding one volume of saturated $\left(\mathrm{NH}_{4}\right)_{2} \mathrm{SO}_{4}$ solution to one volume of serum sample. The mixture was allowed to precipitate for one hour on ice. The precipitate was collected by centrifugation at $48000 \mathrm{~g}$ for 30 minutes. After centrifugation the supernatant was discarded and the precipitate dissolved in a minimum amount of TRIS buffered saline and extensively dialysed against several changes of the buffer.

\section{PURIFICATION OF SERUM IgG AND IgM}

FRACTIONS OF ANTICARDIOLIPIN ANTIBODIES IgG and IgM from the $\left(\mathrm{NH}_{4}\right)_{2} \mathrm{SO}_{4}$ precipitated from the serum was purified on Sepharose columns conjugated with goat antihuman IgG or IgM respectively. After extensive absorption and washing, the IgG and IgM fractions were eluted with $5 \mathrm{M} \quad \mathrm{MgCl}_{2}$ and dialysed extensively against TRIS buffered saline.

\section{MICE}

$\mathrm{BALB} / \mathrm{c}$ mice (8-10 week old females) were purchased from the Sackler Faculty of Medicine, Tel-Aviv University.

DETECTION OF ANTICARDIOLIPIN ANTIBODIES Anticardiolipin activity in serum samples from the immunised mice or in human serum was detected by enzyme linked immunosorbent assay (ELISA) as follows: 96 well ELISA plates (Nunc Immunol, Denmark) were coated with cardiolipin (Sigma) at a concentration of 50 $\mu \mathrm{g} / \mathrm{ml}$ in ethanol. The plates were left open to air at $4^{\circ} \mathrm{C}$ until evaporation had occurred. After blocking of any left blockable sites with phosphate buffered saline (PBS) and 5\% bovine serum, serial dilutions (1:200 to $1: 3600)$ of the human or mice serum samples in PBS and $2 \%$ bovine serum were incubated for two hours. Wells were washed three times with PBS. Bound antibodies were detected using a 1:1000 dilution of goat antihuman or mouse (highly specific and not cross reactive) Ig specific for IgG and IgM conjugated to alkaline phosphatase (Sigma) and the addition of its substrate p-nitrophenylphosphate. Colour was measured in a Titertek ELISA reader at $405 \mathrm{~nm}$. Values greater than two standard deviations above the mean of 10 normal serum samples were considered positive for autoantibody detection.

DETECTION OF ANTIBODIES TO DOUBLE STRANDED DNA, POLYNUCLEOTIDES AND HISTONE

Antibodies to double stranded DNA, poly(I), and poly $(\mathrm{G})$ were determined according to the method of Shoenfeld et al. ${ }^{23}$ Briefly, polystyrene plates with 96 flat bottomed wells (Nunc) were coated sequentially with polyL-lysine $(50 \mu \mathrm{g} / \mathrm{ml}$ in water), the antigen in question, $2.5 \mu \mathrm{g} / \mathrm{ml}$ TRIS buffered saline, and poly-L-glutamate $(50 \mu \mathrm{gg} / \mathrm{ml})$. Washings between steps were performed using TRIS buffered saline with $0.05 \%$ Tween 20 to minimise non-specific binding. Detection of the autoantibodies in the serum samples was as described for anticardiolipin antibodies. Detection of antibodies to histone was carried out using the method of Shoenfeld et al. ${ }^{24}$

DETECTION OF IDIOTYPES IN SERUM SAMPLES AND ON ANTIBODIES

To determine the presence of two common anticardiolipin idiotypes and a common antiDNA idiotype (16/6 idiotype), we used two monoclonal anti-idiotypic antibodies and a polyclonal anti-idiotype: anti-H-3 (S2.9) is a mouse monoclonal antibody defining the $\mathrm{H}-3$ idiotype of a natural anticardiolipin antibody, originally defined on a human monoclonal anticardiolipin antibody $(\mathrm{H}-3) .^{21}$ The $\mathrm{H}-3$ anticardiolipin antibody was previously shown by us to be pathogenic and to induce the antiphospholipid syndrome in naive mice. ${ }^{22}$ 1.10 is an idiotype, originally detected using a mouse monoclonal anti-idiotypic antibody on polyclonal anticardiolipin antibodies from a patient with active SLE. ${ }^{25}$ It was found by us to be more prevalent among patients with the primary antiphospholipid syndrome. ${ }^{26}$ The $16 / 6$ idiotype is a pathogenic idiotype of antibody to DNA described previously ${ }^{27} 28$ and defined by a polyclonal anti-idiotype prepared in rabbit.

Polystyrene plates containing 96 wells (Nunc) were incubated overnight at $4^{\circ} \mathrm{C}$ with duplicates of the anti-idiotypes (H-3), 1.10 or $16 / 6$ ) diluted $1: 200,1: 1000$, and $1: 2000$ respectively in $0.05 \mathrm{M} \mathrm{NaHCO}_{3}$ buffer, $\mathrm{pH}$ $9 \cdot 6$. Plates were washed three times with TRIS buffered saline, $\mathrm{pH} 7 \cdot 4$. After two hours of 
incubation with $5 \%$ bovine serum in TRIS buffered saline, the plates were incubated with either serum samples (samples and normal controls, 1:200) or antibodies $(2 \mu \mathrm{g} / \mathrm{ml})$ diluted in TRIS buffered saline and $2 \%$ bovine serum. After washing with TRIS buffered saline and $0.05 \%$ Tween, alkaline phosphatase conjugated to goat antihuman IgG or IgM (Sigma) was added for four hours at room temperature. The conjugate was previously tested for interspecies cross reactivity and was found to be specific to human immunoglobulins. The rest of the procedure was performed as described earlier.

INHIBITION OF BINDING OF ANTICARDIOLIPIN ANTIBODIES AND ANTIBODIES TO DOUBLE STRANDED DNA

Serum samples at the dilution which gave $50 \%$ of maximum binding to the antigen in question were preincubated with the antigen at different concentrations $(100 \mu \mathrm{g} / \mu \mathrm{l}$ to $0 \cdot 1 \mu \mathrm{g} / \mathrm{ml})$. The preincubation was carried out with cardiolipin, double stranded DNA, or a non-relevant protein (bovine serum albumin) to confirm the specific binding or to show cross reactivity of antibodies.

After incubation of the serum samples with the different inhibitors overnight at $4^{\circ} \mathrm{C}$, the remaining activity was tested by ELISA as detailed earlier. As a control we used the serum incubated without the antigen, but with the appropriate volume of PBS instead. The percentage of inhibition was calculated as follows:

$\%$ inhibition $=\left(\frac{\mathrm{OD} \text { control }-\mathrm{OD} \text { with inhibitor }}{\text { OD control }}\right) \times 100$

INDUCTION OF ANTIPHOSPHOLIPID SYNDROME IN MICE

BALB/c mice (20 in each group) were immunised intradermally into the hind footpads with $1 \mu \mathrm{g}$ of either purified $\mathrm{IgG}$ or IgM from the serum of the patient or from the control, in complete Freund's adjuvant (Difco) as reported previously. ${ }^{18-22}$

Three weeks later boost injections were given with the same amount of antibodies in isotonic PBS into the hind footpads.

BLOOD CELL COUNTS

White blood cell and platelet counts from individual blood samples were measured in diluted blood using a single optical cytometer (Coulter Counter HC Plus Cell Control, Coulter Electronics, United Kingdom).

DETECTION OF LUPUS ANTICOAGULANT

The presence of lupus anticoagulant was evaluated by the prolongation of activated partial thromboplastin time in a mixing test, ${ }^{2}$ adding one volume of plasma (whole blood mixed with sodium citrate, $0.13 \mathrm{~mol} / \mathrm{l}$, in a $9: 1$ ratio), to one volume of cephalin and incubating for two minutes at $37^{\circ} \mathrm{C}$. Another volume of $0.02 \mathrm{M} \mathrm{CaCl}_{2}$ was added and the clotting time was recorded in seconds. The results were confirmed by the kaolin clotting time. ${ }^{22}$

EVALUATION OF OUTCOME OF PREGNANCY The number of vaginal plugs (indicating mating), the number of pregnancies (indicating fecundity), and the number of live embryos for each successful pregnancy were studied according to methods described previously. ${ }^{17-22}$

In addition, the number of resorbed embryos was recorded and the resorption index (\%R) was calculated as follows

$$
\% \mathrm{R}=\left(\frac{\text { No of resorptions }}{\text { No of resorptions }+ \text { No of live embryos }}\right) \times 100
$$

DETERMINATION OF ANTIBODY AFFINITY

The affinity of the various antibodies to cardiolipin bound to a solid phase was determined using the method previously described. ${ }^{29}{ }^{30}$ Briefly, ammonium thiocyanate $\left(\mathrm{NH}_{4} \mathrm{SCN}\right)$ in $0 \cdot 1 \mathrm{M}$ phosphate buffer $(\mathrm{pH}$ 6.0) was added to the appropriate wells precoated with cardiolipin and after incubation with the antibodies in question, at concentrations ranging from 0.1 to $10 \mathrm{~mol} / 1$. The plates were washed after 15 minutes with PBS-Tween and antihuman immunoglobulin conjugated to alkaline phosphatase was added.

The data were fitted to a graph of $\log _{10}(\%$ binding) $v$ molar concentration of $\mathrm{NH}_{4} \mathrm{SCN}$. The affinity index, which is the molar concentration of $\mathrm{NH}_{4} \mathrm{SCN}$ required to reduce the initial absorbance by $50 \%$, was determined.

\section{Results}

CHARACTERISTICS OF PATIENT'S ANTICARDIOLIPIN ANTIBODIES

Sequential blood samples were taken from the 23 year old patient with the primary antiphospholipid syndrome. Samples were taken in 1987 when she was diagnosed and during pregnancy (1991) while being treated with mini-dose aspirin. Figure 1A shows the titres of serum IgG and IgM anticardiolipin antibodies at the time of diagnosis. During pregnancy the levels of IgG anticardiolipin antibodies decreased, whereas a minor increase was noted in the titre of $\operatorname{IgM}$ anticardiolipin antibodies (fig 1B).

IgG and IgM fractions from the patient with antiphospholipid syndrome and the healthy control were purified on affinity columns and tested for their activities to cardiolipin and various autoantigens. The IgG fraction bound to cardiolipin (fig $2 \mathrm{~A}$ ), but did not react with DNA or with the synthetic polynucleotides $\operatorname{poly}(G)$ or poly(I) (data not shown). The IgM fraction bound to cardiolipin, DNA and poly(I) (fig 2B). The IgG and IgM fractions of the healthy control did not react with cardiolipin nor with DNA.

When inhibition assays were performed, the activity of the IgG fraction with cardiolipin was found to be inhibited by cardiolipin but not by DNA (74 v 5\% inhibition respectively) 

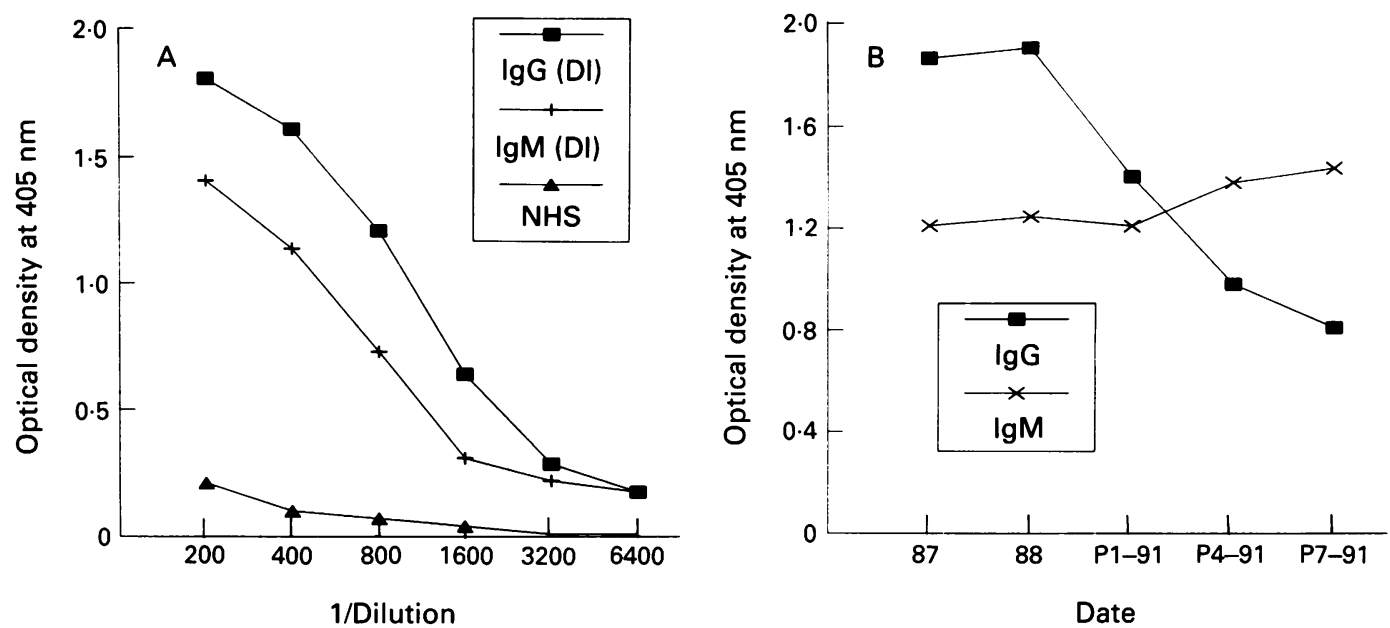

Figure 1 (A) Dilution curve of the binding of a serum sample from a patient with antiphospholipid syndrome (at the time of diagnosis in 1987) to cardiolipin. The titres of serum IgG, IgM, and of a normal human serum (NHS) are shown. (B) Titres of IgG and IgM anticardiolipin antibodies in the serum sample (at a dilution of 1:200) from the patient with the antiphospholipid syndrome before and during pregnancy (P1, P4, and P7 represent the month of gestation).
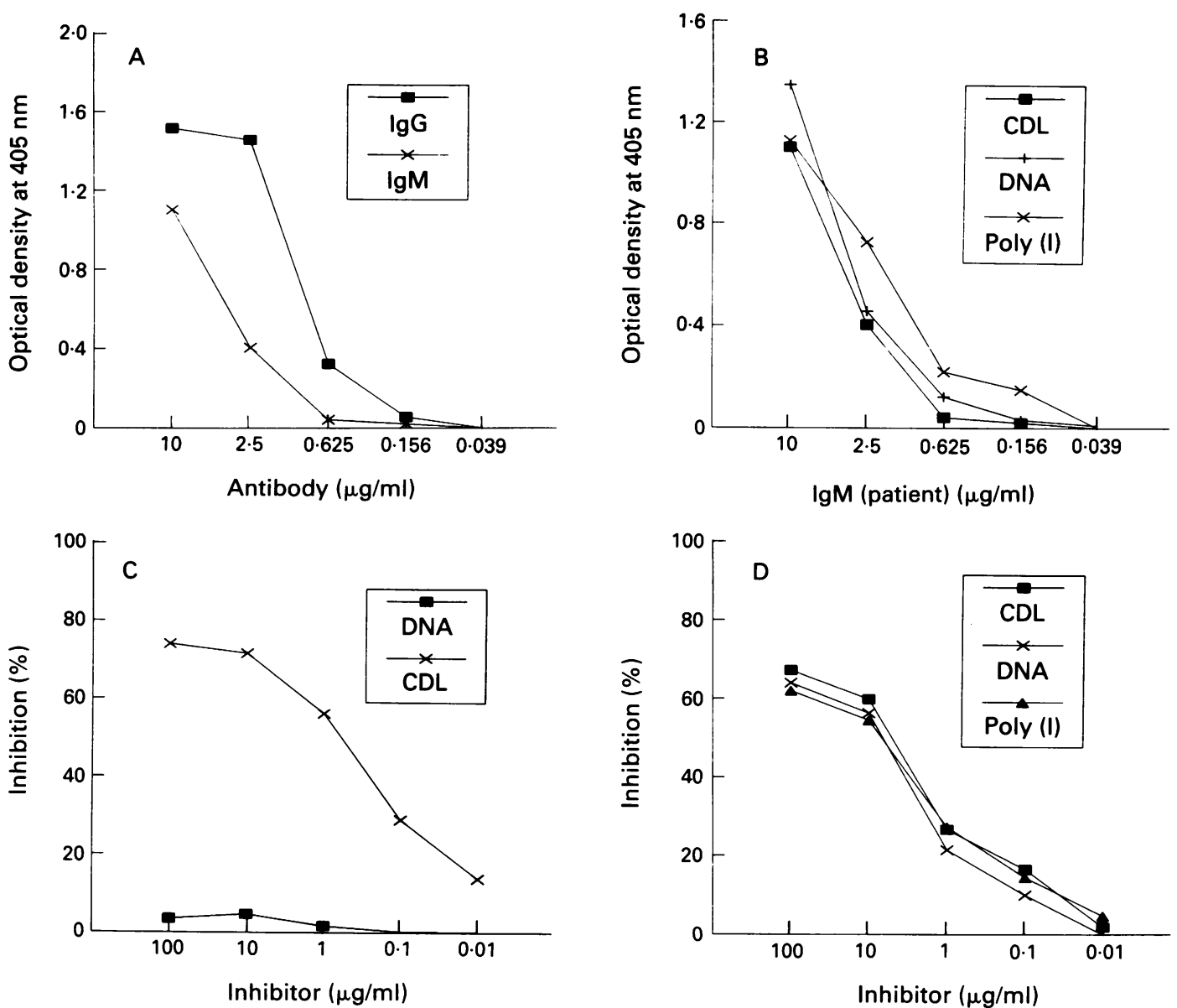

Figure 2 (A) Reactivity of patient serum IgG and IgM fractions with cardiolipin (CDL) at different antibody concentrations. (B) Enzyme linked immunosorbent assay (ELISA) showing the binding of the IgM fraction from the patient to $C D L, D N A$, and poly (I). (C) Inhibition of the binding of the IgG fraction to CDL with CDL and DNA. (D) ELISA in which the binding of the IgM fraction from the patient to $C D L$ is inhibited by $C D L, D N A$, and poly (I) in solution.

(fig 2C). The binding of the IgM fraction to cardiolipin was inhibited by cardiolipin, DNA, and poly(I) (67 $v 6 \quad 64 \quad v \quad 61 \%$ inhibition respectively) (fig $2 \mathrm{D}$ ). Similarly, the IgM binding to DNA was inhibited by DNA and cardiolipin (64 $v 68 \%$ inhibition respectively) (data not shown).

Comparing the affinity of binding to cardiolipin of the two fractions has revealed that IgG binds in a significantly higher affinity than IgM as expressed by the affinity index (3.6 $v 1 \cdot 1 \mathrm{~mol} / \mathrm{l}$ respectively) (fig 3 ).
The IgM fraction was found to carry the anti-DNA $16 / 6$ idiotype only, whereas the IgG fraction carried the two anticardiolipin idiotypes, H-3 and $1 \cdot 10$ (data not shown).

INDUCTION OF ANTIPHOSPHOLIPID SYNDROME IN MICE BY ACTIVE IMMUNISATION

$\mathrm{BALB} / \mathrm{c}$ mice were immunised intradermally into the hind footpad with $1 \mu \mathrm{g}$ of the purified IgG and IgM fractions of anticardiolipin antibodies. A booster injection with the 


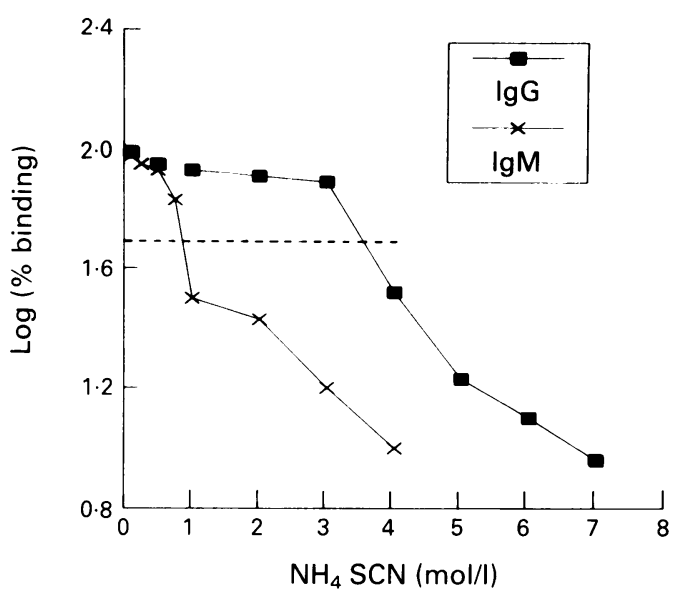

Figure 3 Effect of increasing concentrations of $\mathrm{NH}_{4} \mathrm{SCN}$ on the anticardiolipin binding in an enzyme linked immunosorbent assay (ELISA). Broken line represents log $(50 \%)$ of maximum binding.

immunoglobulin in PBS was given three weeks later. Serial blood samples were drawn periodically every month to determine serological and other haematological findings. High titres of IgG anticardiolipin antibodies were detected in the serum samples of mice immunised with the IgG fraction (fig $4 \mathrm{~A}$ ), whereas a decrease in antibodies to DNA and histone was noted with time (fig 4B). The titre of anticardiolipin antibodies in the serum samples from mice immunised with the IgM fraction of anticardiolipin antibodies decreased with time (fig 4A). Interestingly, the titre of antibodies to DNA in IgM immunised mice remained constantly high.

Mice immunised with the $\operatorname{IgG}$ fraction of anticardiolipin antibodies had a low mean (SD) number of platelets compared with the control mice $\left(0.4(0.06)\right.$ v $\left.1.0(0.09) \times 10^{9} / 1\right)$ and a prolonged mean activated partial thromboplastin time $(64.5 \quad(9 \cdot 7)$ v $30 \cdot 1 \quad(1 \cdot 7)$ seconds). Mice immunised with the $\operatorname{IgM}$ anticardiolipin/DNA fraction had proteinuria and a lower mean (SD) white blood cell count than mice immunised with the control $\operatorname{IgM}$ $\left(3.3(0.3) \times 10^{9} v 8.0(0.2) \times 10^{9} / 1\right.$ respectively) (table). Signs associated with the antiphospholipid syndrome (ie, activated partial thromboplastin time, platelet number) were within the normal range in mice immunised with IgM anticardiolipin antibodies.

A lower fecundity rate was observed in female mice immunised with $\operatorname{IgG}$ and $\operatorname{IgM}$ anticardiolipin antibodies than in controls, whereas a decrease in the number of live embryos for each pregnancy could be noted only in mice immunised with IgG anticardiolipin antibodies (table). A high percentage of resorptions of fetuses (61 (9)\%) could be found only in mice immunised with IgG. A smaller resorption rate $(12(9) \%)$ was noted in mice immunised with IgM; controls had only $3(5) \%$ resorptions $(p<0 \cdot 001)$. The mean $(\mathrm{SD})$ of the weights of the embryos and placentas derived from mice immunised with IgG

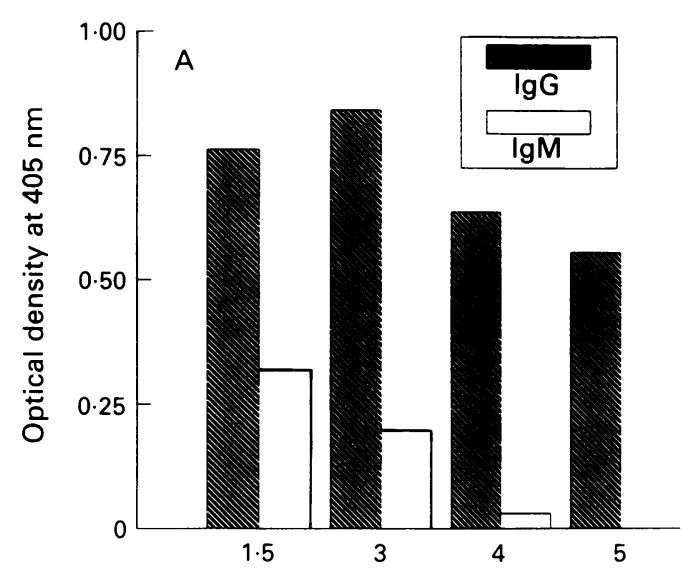

Months after immunisation

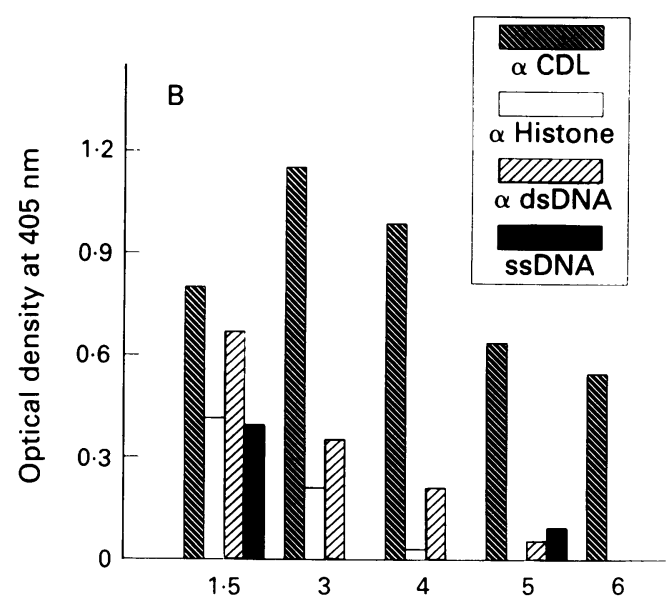

Months after immunisation

Figure 4 (A) Titres of anticardiolipin antibodies in the serum of a representative mouse immunised with IgG or IgM fractions purified from the patient with the antiphospholipid syndrome during a period of six months after the booster injection. (B) Titres of different autoantibodies in the serum of a representative mouse immunised with IgG fraction derived from the serum of the patient with antiphospholipid syndrome.

Findings in mice immunised with anticardiolipin antibodies derived from a patient with antiphospholipid syndrome (Patient, IgG and IgM) or with a normal control serum (NC, IgG and IgM)

\begin{tabular}{lcccc}
\hline Parameters & IgG patient & IgM patient & IgG NC & $I g M N C$ \\
\hline Fecundity & $5 / 14(36)$ & $4 / 13(30)$ & $5 / 8(62)$ & $12 / 25(48)$ \\
Mean (SD) No of live embryos/pregnancy & $3 \cdot 25(0 \cdot 5)$ & $8 \cdot 1(0 \cdot 4)$ & $8 \cdot 75(1)$ & $8(2)$ \\
Mean (SD) embryo weight (mg) & $641(210) \ddagger$ & $1134(180)$ & $1303(105) \ddagger$ & $1295(120)$ \\
Mean (SD) weight of placenta (mg) & $103(14) \ddagger$ & $136(11)$ & $145(8) \ddagger$ & $140(10)$ \\
Resorptions (R) (\%R = R + F) & $61(9) \oint$ & $12(9) \oint$ & $5(4)$ & $3(5)$ \\
Mean (SD) APTT (seconds) $\dagger$ & $64 \cdot 5(9 \cdot 7)$ & $32 \cdot 8(5 \cdot 7)$ & $30 \cdot 1(1 \cdot 7)$ & $30(4)$ \\
Mean (SD) platelets $\left(\times 10^{\%} / 1\right)$ & $397(59)$ & $1097(163)$ & $994(92)$ & $987(34)$ \\
White blood cells $\left(\times 10^{9} / 1\right)$ & $7 \cdot 5(0 \cdot 3)$ & $3 \cdot 3(0 \cdot 3)$ & $8 \cdot 2(0 \cdot 3)$ & $8 \cdot 0(0 \cdot 2)$ \\
\hline
\end{tabular}

$\star$ No (\%) of pregnancies.

+ APTT = activated partial thromboplastin time measured in plasma in the presence of cephalin and $\mathrm{CaCl}_{2}$.

$\ddagger \mathrm{p}<0 \cdot 005$, calculated using rank sum two sample test.

$\S \mathrm{p}<0.001$, calculated using $\chi^{2}$ test. 
anticardiolipin antibodies was lower than in control mice (641 (210) v 1303 (105) $\mathrm{mg}$ and 103 (14) $v 145$ (8) mg respectively; $\mathrm{p}<0.005)$. No similar effects were observed in embryo and placentas from mice immunised with IgM anticardiolipin antibodies.

\section{Discussion}

In this study we have shown that active immunisation of mice with human serum IgG anticardiolipin antibody led to the production by the mouse of pathogenic anticardiolipin antibodies. We believe that this induction is carried out through the idiotypic network, first generating anti-anticardiolipin antibodies (Ab2 or anti-idiotype), then resulting in production of anti-anti-anticardiolipin antibodies (Ab3 or anti-anti-idiotype) which have, among other properties, similar binding characteristics to $\mathrm{Ab} 1$ (human anticardiolipin antibodies). The turning on of the idiotypic cascade has been shown previously in many studies ${ }^{31}$ and the molecular mimicry between $\mathrm{Ab} 1$ and $\mathrm{Ab} 3$ was similarly confirmed, including the amino acid sequence of the CDRs of heavy chains. ${ }^{32}$

Previously, using the same technique of immunisation, we showed that after the injection of $16 / 6$ idiotype carrying antibodies to DNA we could induce an SLE-like syndrome in mice, associated with mouse antibodies to DNA. ${ }^{181922}$ A similar scenario could account for the emergence of the mouse anticardiolipin antibodies. Furthermore, in the SLE mice, the serum samples also contained other characteristic SLE autoantibodies (eg antibodies to Sm and histone). Thus it seems that pathogenic anti-DNA idiotypes may induce the generation of regulatory idiotypes, capable by themselves of influencing the production of other autoantibodies. We have supported our experience in the antiphospholipid syndrome and SLE with a third autoimmune disorder, namely primary biliary cirrhosis (Blank $M$, Guilburd B, Shoenfeld Y, unpublished data).

Although the pathogenicity of $16 / 6$ idiotype was questioned by Isenberg et al, ${ }^{33}$ these workers did not use the same 16/6 idiotype as us, and injected the mice in a different immunisation schedule, which resulted in mice with a different autoimmune disorder, namely adjuvant arthritis. ${ }^{34}$ In contrast, our results were confirmed by others, ${ }^{35}$ who presented an experimental SLE in naive mice after immunisation with polyclonal antibodies to DNA positive for the 16/6 idiotype, which were derived from a patient with active SLE. The combination of high titres of antibodies to DNA, leucopenia, and proteinuria may suggest the emergence of an experimental SLE-like disorder in the mice immunised with IgM anticardiolipin antibodies (16/6 idiotype positive)..$^{18} 19$

Our studies, in which immunisation with one antibody leads to the generation of an antibody with the same specificity, are supported by several other experiments. ${ }^{36-39}$ In the first two reports immunisation with monoclonal antibodies to $\mathrm{Sm}$ resulted in the production of antibodies to $\mathrm{Sm}$. We believe that the basic mechanism of these inductions entails dysregulation of the idiotypic network, inducing the emergence of regulatory idiotypes, although the authors of one of these studies $^{37}$ do not believe that it is the idiotypic network which is responsible for the idiotypic cascade occurring.

The patient whose immunoglobulins were used in this study had the classical antiphospholipid syndrome. Although the activity of antibodies to single stranded DNA (but not double stranded DNA) was detected in her serum samples, she may still be regarded as having the primary antiphospholipid syndrome, as several groups were able to show antibodies to single and double stranded DNA in serum samples of patients with primary antiphospholipid syndrome. ${ }^{25}$ The patient's disease may switch in the future to SLE. On the other hand, she may remain with the primary antiphospholipid syndrome only.

The antiphospholipid syndrome is associated with many obstetric complications. We saw the classical signs of the antiphospholipid syndrome (that is, thrombocytopenia, prolonged activated partial thromboplastin time, and fetal loss) in the mice immunised with the IgG anticardiolipin antibodies which carried the pathogenic idiotypes $1 \cdot 10$ and $\mathrm{H}-3$. From the results of this study it seems as if it is also complicated by a low fecundity rate. In this respect IgG and IgM immunised mice had low fecundity rates $(36 v 62 \%$ and $30 v 48 \%$; see table). It is conceivable that some of the cases of unexplained sterility in women may be related to high titres of anticardiolipin antibodies. Therefore these women should also routinely be screened for the presence of such antibodies.

Our study also shed light on another aspect of the antiphospholipid syndrome: the relationships between anticardiolipin antibodiesnamely, the existence of pathogenic and nonpathogenic anticardiolipin antibodies. Previously we have shown that idiotypes (antiDNA idiotypes) could be either pathogenic or non-pathogenic. ${ }^{19}$ If repeated, our model may serve to determine whether anticardiolipin antibodies which are incidently found in serum are indeed pathogenic, thus necessitating preventive lifelong anticoagulant treatment.

The results of this study also point to the possible pathogenetic importance of the isotype, idiotype and affinity of anticardiolipin antibodies.

We thank Dr A Hohmman from Flinders, South Australia for providing the anti-H-3 (S2.9) anti-idiotypic antibody. This study was supported by a Basic Foundation Grant, Israel Academy of Sciences, and the Burton's Fund for Research in Autoimmunity.

1 Asherson R A. A “primary" anti-phospholipid syndrome. $f$ Rheumatol 1988; 15: 1742-6.

2 Alarcon-Segovia D, Sanchez-Guerrero J. Primary antiphospholipid syndrome. I Rheumatol 1989; 16: $482-8$.

3 Hughes G R V, Harris E N, Gharavi A E. The anticardiolipin syndrome. $\mathcal{F}$ Rheumatol 1986; 13: 486-9.

4 Lockshin M D. Anti-cardiolipin antibody [editorial] Arthritis Rheum 1987; 30: 471-2.

5 Khamashta M A, Harris E N, Gharavi A E, et al. Immune mediated mechanism for thrombosis: anti-phospholipid antibody binding to platelet membrane. Ann Rheum Dis 1988; 47: 849-54. 
6 Asherson R A, Khamashta M A, Ordi-Ros J. The "primary" antiphospholipid syndrome: major clinical and serological antiphospholipid syndrome: major clinical and se

7 Tomer Y, Kessler A, Eyal A, Many A, Shoenfeld Y. Superior vena cava occlusion in a patient with antiphospholipid antibody syndrome. F Rheumatol 1991; 18: 95-7.

8 Harris E N, Asherson R A, Gharavi A E, Morgan S H Derue G, Hughes $G$ R. Thrombocytopenia in SLE and related autoimmune disorders: association with anti-cardiolipin antibody. $\mathrm{Br} f$ Haematol 1985; 59: 227-30.

9 Mueh J R, Herbst K D, Rapaport S L. Thrombosis in patients with the lupus anticoagulant. Ann Intern Med 1980; 92: 156-9.

10 Bowie E J W, Thompson J H Jr, Pascuzzi C A, Owen C A Jr. Thrombosis in systemic lupus erythematosus despite circulating anticoagulants. F Lab Clin Med 1964; 62: 416-30.

11 Shaulian E, Shoenfeld Y, Berliner S, Shaklai M, Pinkhas J. Surgery in patient with circulating anti-coagulant. Int Surg 1981; 66: 157-9.

12 Lockshin M D, Druzin M L, Oamar T. Prednisone does not prevent recurrent fetal death in women with antiphospholipid antibody. Am $\mathcal{f}$ Obstet Gynecol 1989; 160: 439-43.

13 Rosove M H, Tabsh K, Howard P, et al. Heparin therapy for prevention of fetal wastage in woman with anticardiolipin antibodies and lupus anticoagulant. Blood 1987; 70 (suppl 1): 379a.

14 Carreras L O, Perez G N, Vega H R, Casavilla F. Lupus anticoagulant and recurrent fetal loss: successful treatment with gammaglobulin. Lancet 1988; ii: $393-4$.

15 Gharavi A E, Mellors R C, Elkon K B. IgG anti-cardiolipin antibodies in murine lupus. Clin Exp Immunol 1989; 78: 233-8.

16 Branch D W, Dudley D J, Mitchell M D, et al. Immunoglobulin $G$ fractions from patients with antiphospholipid antibodies cause fetal death in BALB/c mice: a model for autoimmune fetal loss. Am $\mathcal{F}$ Obste Gynecol 1990; $163: 210-6$

17 Blank M J, Cohen J, Toder V, Shoenfeld Y. Induction of anti-phospholipid syndrome in mice with mouse lupus monoclonal and human polyclonal anti-cardiolipin antibodies. Proc Natl Acad USA Sci 1991; 88: 3069-73.

18 Mendlovice S, Brocke S, Shoenfeld Y, et al. Induction of a systemic lupus erythematosus like disease in mice by a common anti-DNA idiotype. Proc Natl Acad Sci USA 1988; 85: 2260-4

19 Blank M, Krup M, Mendlovic S, et al. The importance of the pathogenic 16/6 idiotype in the induction of SLE in naive mice. Scand f Immunol 1990; 31: 45-52.

20 Fricke $\mathrm{H}$, Offen $\mathrm{D}$, Mendlovic S, et al. Induction of experimental systemic lupus erythematosus in mice by immunization with a monoclonal anti-La autoantibody. Int Immunol 1990; 2: 225-30.

21 Hohmman A, Comacchio R, Boswarva V, Sutjita $M$ Bradley J. The H-3 anti-phospholipid idiotype is found in patients with SLE but not in patients with syphilis. Clin Exp Immunol 1989; 86: 207-1 1.

22 Bakimer R, Fishman P, Blank M, Sredni B, Djaldetti $M$ Shoenfeld Y. Induction of primary anti-phospholipid syndrome in mice by immunization with a human monoclonal anti-cardiolipin antibody $(\mathrm{H}-3)$. F Clin Invest 1992; 89: 1558-63.
23 Shoenfeld Y, Hsu-Lin S C, Gabriels J E, et al. Production of autoantibodies by human-human hybridomas. $\mathcal{F}$ Clin Invest 1982; 70: 205-8.

24 Shoenfeld Y, Segol G, Segol O, Stollar B D, Isenberg D A. Anti-histone antibodies in the serum of lupus patients and their relatives. Arthritis Rheum 1987; 30: 169-75.

25 Valesini G, Tincani A, Harris E N, et al. Use of monoclonal antibodies to identify shared idiotypes on anti-cardiolipin and anti-DNA antibodies in human sera. Clin Exp Immunol 1987; 70: 18-25.

26 Krause I, Cohen J, Blank M, et al. Distribution of two common idiotypes of anticardiolipin antibodies in sera of patients with primary antiphospholipid syndrome, systemic lupus erythematosus and monoclonal gammopathies. Lupus ₹ 1992; 1: 92-6.

27 Shoenfeld Y, Mozes E. Pathogenic idiotypes of anti-DNA antibodies and autoimmunity. FASEB $\mathcal{f}$ 1990; 4: 2546-51.

28 Shoenfeld Y, Isenberg D A, Rauch J, Madaio M P, Stollar B D, Schwartz R S. Idiotypic cross reactions of monoclonal human lupus antibodies. 7 Exp Med 1983; 158: $718-30$

29 Pullen G R M, Fitzgerald M G, Hosking C S. Antibody avidity determination by ELISA using thiocyanate elution. F Immunol Methods 1986; 86: 83-7.

30 MacDonald R A, Hosking C S, Jones C L. The measurement of relative antibody affinity by ELISA using thiocyanate elution. f Immunol Methods 1988; 106: 191-4.

31 Roth C, Somme G, Schiff C, Theze J. Immune response against poly(Glu 60, Ala 30, Tyr 10) (GAT). Immunization with monoclonal anti-idiotypic antibodies leads to the predominant stimulation of idiotypically similar immunoglobulins with anti-GAT activity. Eur f Immunol 1985; 15: 576 .

32 Fougereau M, Corbet S, Mazza G, et al. The GAT system: a possible germ line idiotypic network. In: Reichlin $M$, Capra J D, eds. Idiotypes. New York: Academic Press,

33 Isenberg D A, Katz D, Le Page S, et al. Independent analysis of the 16/6 Id lupus model. F Immunol 1991; 147: 4172-7.

34 Knight B, Katz D R, Isenberg D A, et al. Induction of adjuvant arthritis in mice. Clin Exp Immunol 1992; 90: 459-65.

35 Tincani A, Balestrieri G, Allegri F, Fornasteri A, Sinico L A. Induction of experimental SLE in naive mice by immunization with serum polyclonal anti-DNA antibody carrying the 16/6. Clin Exp Rheumatol 1993; 11: 129-37.

36 Stocks $M R$, Williams $D$, Maini $R$ R Differential induction of lupus associated anti-nuclear antibodies in induction of lupus associated anti-nuclear antibodies in Immunol 1987; 67: 492-9.

37 Eisenberg R A, Pisetsky D S, Craven S Y, Grudier J P, O'Donnell M, Cohen P L. Regulation of the anti-Sm O'Donnell M, Cohen P L. Regulation of the anti-Sm autoantibody response in SLE mice by mono

38 Rombach E, Stetler D A, Brown J C. Rabbits produce SLElike anti-RNA polymerase I and anti-DNA autoantibodies in response to immunization with either human or murine SLE anti-DNA antibodies. Autoimmunity 1992; 13: 291-302.

39 Dang H, Lazaridis K, Talal N. Induction of autoantibodies in normal BALB/c mice by perturbation of the idiotypic network. Arthritis Rheum 1992; 35 (suppl). 